\title{
PERLINDUNGAN HUKUM TERHADAP ANAK DALAM KELUARGA POLIGAMI DITINJAU DARI HUKUM ISLAM DAN HUKUM POSITIF
}

\author{
Warsono \\ Institut Agama Islam (IAI) An Nur Lampung \\ Email: warsonoluwes79@gmail.com
}

\begin{abstract}
This study aims to analyze the implementation of legal protection for children in polygamous families in terms of Islamic and positive law in Metro City, the inhibiting factors and efforts to overcome the obstacles that occur in polygamous families in terms of Islamic law and positive law in Metro City. This research is descriptive qualitative. Data collection was done by means of interviews and documentation. Data were analyzed by means of data reduction, data presentation and drawing conclusions. Based on the results of the analysis, the implementation of legal protection for children in a polygamous family in terms of Islamic law and positive, that is, legally positive has not been carried out well, but there is one family that is carried out, this is due to several factors, namely raising and caring for children, meeting all the necessities of life. and maintaining honor, responsibility, guiding and educating, as well as maintaining the health and welfare of children. Meanwhile, from Islamic law, there is something that is well implemented and also unlike the child's right to live, namely, children's rights in the clarity of their lines, children's rights in giving a good name, children's rights to obtain breast milk, children's rights to receive care, children's rights in property ownership. objects, children's rights in obtaining education and teaching. The factors that inhibit the needs of polygamous children, the educational factor of children in polygamous families, the factors of the relationship between children from polygamous families, and the factors of the relationship between children and parents. As well as efforts to overcome obstacles that occur in a polygamous family, namely upholding the husband's leadership in the family, the objectivity and neutrality of the husband, husband's justice, the husband acts wisely, the husband's love, the husband dares to give in for the sake of family harmony, the husband can maintain a balance of rights and obligations.
\end{abstract}

Keywords: Legal Protection, Children in a Polygamous Family, Islamic Law, Positive Law.

\section{A. Pendahuluan}

Perkawinan bertujuan untuk membentuk keluarga yang bahagia dan kekal, dapat diartikan bahwa perkawinan itu haruslah berlangsung seumur hidup dan tidak boeh diputuskan begitu saja. Hubungan kekeluargaan ini sangat penting, karena ada sangkut pautnya dengan hubungan anak dengan orang tua, pewaris, perwalian dan pengampuan. ${ }^{1}$ Dengan perkawinan akan timbul ikatan yang berisi hak dan kewajiban, umpamanya kewajiban untuk bertempat tinggal yang sama, setia kepada satu dan lainnya. Dalam Undang-Undang Nomor 1 Tahun 1974 tentang Perkawinan disebutkan dalam Pasal I bahwa perkawinan ialah ikatan lahir batin antara seorang

1 Ali Afandi, Hukum Waris, Hukum Keluarga, Hukum Pembuktian Menurut Kitab Undang-Undang Hukum Perdata (BW), (Jakarta: PT. Bina Aksara, 1984), h. 93. 
pria dan seorang wanita sebagai suami isteri, dengan tujuan membentuk keluarga (rumah tangga) yang bahagia dan kekal berdasarkan Ketuhanan Yang Maha Esa.

Suatu perkawinan tidak hanya didasarkan pada ikatan lahir saja atau ikatan batin saja, tetapi merupakan perwujudan ikatan lahir dan batin. Ikatan lahir tercermin adanya akad nikah, sedangkan ikatan batin adanya perasaan saling mencintai dari kedua belah pihak. Walaupun demikian dalam keadaan-keadaan tertentu lembaga perkawinan yang berasaskan monogami dalam Pasal 3 UU No 1 Tahun 1974 menyebutkan bahwa, (1) Pada azaznya dalam suatu perkawinan seorang pria hanya boleh mempunyai seorang isteri. Seorang wanita hanya boleh mempunyai seorang suami; (2) Pengadilan dapat memberi izin pada seorang suami untuk beristeri lebih dari seorang apabila dikehendaki oleh pihak-pihak yang bersangkutan.

Hal demikian poligami sulit dihindari, sebab poligami terjadi karena berbagai macam sebab, antara lain adanya kekurangan pada. Pihak isteri sementara pihak suami enggan menceraikan isterinya karena berbagai alasan. Di samping itu juga disebabkan isteri tidak dapat menjalankan kewajibannya sebagai isteri, seperti cacat fisik atau mental dan tidak dapat memberikan keturunan. Dalam Islam, poligami mempunyai arti perkawinan yang lebih dari satu dengan batasan, umumnya dibolehkan hanya sampai empat wanita. Walaupun ada juga yang memahami ayat tentang poligami dengan batasan lebih dari empat atau bahkan lebih dari sembilan isteri. Perbedaan ini disebabkan dalam memahami dan menafsirkan ayat 3 surat AnNisa, sebagai dasar penetapan hukum poligami. Dengan kata lain, poligami ialah mengamalkan beristeri lebih dari satu yaitu dua, tiga atau empat. ${ }^{2}$ Hal ini juga disebutkan dalam Pasal 55 Ayat (1) KHI bahwa beristeri lebih dari satu orang pada waktu yang bersamaan, terbatas hanya sampai empat orang isteri. ${ }^{3}$

Untuk berpoligami pada saat ini tidaklah dapat dilakukan setiap laki-laki dengan begitu saja. Pemerintah melalui istansinya yang ditunjuk untuk itu ikut campur dalam urusan keinginan seseorang suami yang ingin beristeri lebih dari seorang (poligami). Dengan demikian setiap laki-laki sekarang harus mempunyai alasan yang dapat diterima undang-undang untuk berpoligami. Ini berarti bahwa poligami sekarang sudah dipersulit.

Orang yang beragama Islam selama ini yang menurut Hukum Islam boleh mempunyai isteri dua, tiga, dan empat, setelah berlakunya Undang-undang Nomor 1 Tahun 1974 sudah semakin sukar, karena pemerintah telah ikut campur tangan dalam menentukan keinginan suami yang ingin melakukan perkawinan dengan seorang wanita sebagai isteri kedua, ketiga, atau keempat. Seorang suami yang ingin kawin dengan seorang perempuan janda atas dasar pertimbangan kemanusiaan, yaitu karena merasa kasihan terhadap anak janda yang tidak mempunyai ayah lagi, tidak dapat dijadikan alasan untuk kawin kedua kalinya, karena alasan pertimbangan kemanusiaan yang disebut demikian itu tidak dapat diterima oleh Undang- Undang Nomor 1 Tahun 1974 tentang Perkawinan. Allah SWT berfirman dalam Q.S. Ar-Rum ayat 21 .

2 Selamat Kasmuri, Pedoman Mengayuh Bahtera Rumah Tangga, (Jakarta: Kalam Mulia, 1998), h. 19.

3 Seri Perundangan, Kompilasi Hukum Islam, (Yogyakarta: Pustaka Widyatama, 2005), h.30. 
"Dan di antara tanda-tanda kekuasaan-Nya ialah Dia menciptakan untukmu istri-istri dari jenismu sendiri, supaya kamu cenderung dan merasa tentram kepadanya, dan dijadikan-Nya di antaramu rasa kasih dan sayang. Sesungguhnya pada yang demikian itu benar-benar terdapat tanda-tanda bagi kaum yang berfikir. 4

Undang-undang No. 23 Tahun 2002 tentang Perlindungan Anak dan Undangundang No. 35 Tahun 2014 tentang Perubahan Atas Undang-undang No. 23 Tahun 2002 tentang Perlindungan Anak, yang dimaksud dengan anak adalah seseorang yang belum berusia 18 (delapan belas) tahun termasuk anak yang masih dalam kandungan. ${ }^{5}$

Anak adalah tunas, potensi, dan generasi penerus cita-cita bangsa, memiliki peran strategis dalam menjamin eksistensi bangsa dan negara di masa mendatang. Agar mereka kelak mampu memikul tanggung jawab itu, maka mereka perlu mendapat kesempatan yang seluas-luasnya untuk tumbuh dan berkembang secara optimal, baik fisik, mental, sosial, maupun spiritual. Mereka perlu mendapatkan hakhaknya, perlu dilindungi dan disejahterakan. ${ }^{6}$

Anak-anak perlu mendapat perlindungan hukum demi menjamin hak-hak mereka. Mereka adalah aset negara yang paling penting untuk diperhatikan. Mereka adalah penerus cita-cita perjuangan bangsa. Kepadanyalah digantungkan dimasa yang akan datang. Karena itu perhatian yang besar sudah sepantasnya diberikan dalam rangka menyongsong hari esok yang lebih baik.

Tanggung jawab terhadap pemeliharaan anak adalah tanggung jawab semua pihak (pemerintah, masyarakat, dan keluarga). Keluarga (orang tua) adalah pihak pertama dan utama yang bertanggung jawab terhadap pemeliharaan anak, yang tersebut dalam UU No 4 tahun 1979 tentang kesejahteraan Anak. Seperti yang telah disebutkan di atas bahwa poligami itu dapat membawa akibat buruk terhadap perkembangan kehidupan anak. Karena itu diperlukan adanya aturan-aturan hukum yang jelas mengenai perlindungan orang tua terhadap anak dalam perkawinan poligami. Kompilasi hukum Islam pasal 55 ayat 2 dijelaskan bahwa syarat utama beristri lebih dari seorang, suami harus mampu berlaku adil terhadap istri dan anakanaknya. ${ }^{7}$

Hasil survey wawancara awal diperoleh informasi bahwa berpoligami itu harus mampu bersikap adil terhadap istri dan anak-anaknya, hidup rukun saling mengasihi satu sama lain, tidak membedakan rasa kasih sayang anak istri pertama dengan anak istri kedua. Namun ada pernyataan yang berbeda bahwa jika berpoligami tanpa sepengetahuan istri pertama, maka tidak akan bisa bersikap adil terutama pada anak dari istri kedua, memberi nafkah lahir saja harus sembuyi-sembunyi. Keterangan tersebut menjelaskan bahwa masih ada keluarga poligami yang mampu bersikap adil terhadap kedua istrinya dan anak-anaknya, namun ada juga keluarga yang berpoligami anak-anaknya terlantar kasih sayang dan perlindungannnya oleh karena

4 Departemen Agama RI, Al-Qur'an dan Terjemahnya, (Jakarta: Pustaka Al Fatih, 2009), h. 406.

${ }^{5}$ Lembaran Negara RI, UU No. 23 Tahun 2002 tentang Perlindungan Anak dan UU No. 35 Tahun 2004 tentang Perubahan atas UU Mo. 23 Tahun 2002 tentang Perlindungan Anak pasal 1 ayat 1.

${ }^{6}$ Abu Huraerah, Child Abuse (Kekerasan terhadap Anak), (Bandung: Nuansa, 2007), h. 11.

7 Abdurrahman, Kompilasi Hukum Islam di Indonesia, (Jakarta: Akademika Pressindo, 2010), h. 126. 
itu, untuk melihat pelaksanaan dalam praktiknya maka sangat potensi dilakukan penelitian terhadap masalah anak dalam keluarga poligami.

Adapun rumusan masalahnya adalah bagaimana pelaksanaan perlindungan hukum terhadap anak dalam keluarga poligami ditinjau dari hukum Islam dan hukum positif di Kota Metro? Faktor-faktor apa yang menghambat pelaksanaan perlindungan hukum terhadap anak dalam keluarga poligami ditinjau dari hukum Islam dan hukum positif di Kota Metro? dan bagaimanakah upaya penanggulangan terhadap hambatan yang terjadi dalam keluarga poligami ditinjau dari hukum Islam dan hukum positif di Kota Metro?

\section{B. Pembahasan}

Berdasarkan penelitian yang diperoleh, pelaksanaan perlindungan hukum terhadap anak dalam keluarga poligami ditinjau dari hukum Islam dan hukum positif. Sebelum melakukan analisis, akan dimaparkan kaitan pelaksanaan perlindungan hukum terhadap anak dalam keluarga poligami ditinjau dari hukum Islam dan positif. Dalam Islam terdapat beberapa petunjuk tentang perlindungan terhadap hak anak-anak yaitu:

\section{Hak Anak untuk Hidup}

Sebagaimana disebutkan dalam Q.S. Al-Isra' ayat 31.

Dan janganlah kamu membunuh anak-anakmu Karena takut kemiskinan. kamilah yang akan memberi rezki kepada mereka dan juga kepadamu. Sesungguhnya membunuh mereka adalah suatu dosa yang besar."8

Islam memberikan penghargaan dan perlindungan yang sangat tinggi kepada hak hidup anak baik ketika dia masih dalam kandungan maupun ketika telah dilahirkan.

\section{Hak Anak dalam Kejelasan Nasabnya}

Kejelasan nasab sangat urgen dalam menentukan statusnya untuk mendapatkan hak-hak dari orang tuanya, dan secara psikologis anak juga mendapatkan ketenangan dan kedamaian sebagaimana layaknya manusia. Hal ini tertulis dalam firman Allah SWT di Q.S. Al-Ahzab ayat 5. "Panggillah mereka (anak angkat itu) dengan (memakai) nama bapak-bapak mereka; itulah yang adil di sisi Allah." 9 Anak hasil perkawinan baik resmi maupun tidak resmi berhak mendapat kejelasan hak dalam nasabnya, karena itu akan mempengaruhi perkembangan hidup anak.

\section{Hak Anak dalam Pemberian Nama yang Baik.}

Nama bagi anak-anak sangat penting karena akan berpengaruh pada bagaimana lingkungan anak tersebut memperlakukan dalam pergaulan sosialnya. Bahkan nama bagi anak juga dapat membentuk konsep dirinya, apakah konsep diri yang positif atau negatif tergantung pada nama yang

8 Departemen Agama RI, Al-Qur'an dan Terjemahnya..., h. 285.

9 Ibid, h. 418. 
diberikan oleh lingkungannya. Pemberian nama kepada anak itu adalah hak atau tanggung jawab orangtua, karena bagi anak sangat penting dan berpengaruh di lingkungan sekitar tempat tinggal. Jelaslah bahwa nama bagi anak itu sangatlah penting dan juga tanggung jawab dari orang tua, sesuai dengan hukum Islam dalam hadis Rasulullah saw sebagai berikut:

"Telah menceritakan kepada kami Amru bin Aun berkata: Musyaddad telah mengabarkan dan menceritakan kepada kami, Hasyim berkata dari Daud bin Amru bin Abdillah bin Abi Zakaria dari Abu Darda' berkata: Rasulullah SAW bersabda: Sesungguhnya engkau akan dipanggil nanti di hari kiamat dengan nama-namamu sekalian serta dengan nama-nama bapak-bapakmu, maka baguskanlah nama-namamu". ${ }^{10}$

\section{Hak Anak dalam Memperoleh ASI.}

Ibu menyusui merupakan tanggung jawab moral yang bersifat sunah karena kebaikan ASI untuk bayi jelas manfaatnya terutama ibu kandungnya sendiri. Hubungan yang terjalin pada proses penyusuan selama kurang lebihnya dua tahun merupakan proses pembentukan kepribadian anak tahap awal, di mana kasih sayang ibu akan terukir dalam kepribadian anak, sehingga diharapkan akan berlanjut pada hubungan harmonis anak dan ibu sepanjang usianya.

\section{Hak Anak Mendapatkan Asuhan}

Pembentukan jiwa anak sangat dipengaruhi oleh cara perawatan dan pengasuhan anak sejak dia dilahirkan. Demikian pula perkembangan psikologis anak juga mengalami fase-fase yang memiliki karakteristik yang berbeda-beda sesuai dengan tingkat perkembangan jiwanya. Lingkungan terutama orang tua memiliki andil yang cukup besar dalam menentukan tumbuh kembang anak. Oleh karena itu hak pengasuhan anak secara ideal adalah orang tua sendiri, kecuali ada halangan syara' yang mengharuskan pindahnya hak asuh dari orang tua kepada orang tua lain yang lebih menjamin tumbuh kembang anak dengan baik.

\section{Hak Anak dalam Kepemilikan Harta Benda.}

Hukum Islam menetapkan anak yang baru dilahirkan telah menerima hak waris. Hak waris maupun harta benda lainnya, tentu belum dapat dikelola oleh anak karena keterbatasan kemampuan untuk melakukannya. Karena itu, orang tua atau orang yang dapat dipercaya terhadap amanat ini dapat mengelola hak atas harta benda anak untuk sementara waktu sampai ia mampu untuk mengelola sendiri. Dengan demikian orang tua atau orang terdekat dari kehidupan anak diwajibkan untuk melindungi atau mengurus harta benda anak untuk sementara waktu sampai ia mampu untuk mengelola sendiri. Sebagaimana firmal Allah SWT dalam Q.S. Al-Isra ayat 34.

10 Al-Sijistany, Abu Dawud Sulaiman al-Asy'ast Sunan Abu Dawud, Kitab: Al Adab bab: Fi Taghyiri al Asma', Riy adh: Maktabah al Ma'arif Li al-Nasyr wa at-Tawzi, h. 895. 
"Dan janganlah kamu mendekati harta anak yatim, kecuali dengan cara yang lebih baik (bermanfaat) sampai ia dewasa, dan penuhilah janji, karena janji itu pasti diminta pertanggung jawabannya."11

\section{Hak Anak dalam Memperoleh Pendidikan dan Pengajaran.}

Pendidikan bagi anak merupakan kebutuhan vital yang harus diberikan dengan cara-cara yang bijak untuk menghantarkannya menuju kedewasaan dengan baik. Hak yang terakhir yang harus diterima oleh anak dalam poligami adalah hak anak dalam memperoleh pendidikan dan pengajaran. Seorang anak berhak mengecam pendidikan mulai dari sekolah dasar sampai dengan perguruan tinggi dan itu sudah menjadi tanggung jawab orang tua. Jika salah dalam mendidik maka akan berakibat rusaknya generasi yang akan datang, dan akan mendatangkan kerugian dari orang tua itu sendiri.

Faktor-faktor Penghambat Pelaksanaan Perlindungan Hukum terhadap Anak dalam Keluarga Poligami di Kota Metro Ditinjau dari Hukum Islam dan Positif sebagai berikut:

\section{Faktor Kebutuhan Anak-Aanak Poligami}

Allah SWT berfirman dalam Q.S. Ar-Rum: 21 sebagai berikut:

"Dan di antara tanda-tanda kekuasaan-Nya ialah Dia menciptakan untukmu istri-istri dari jenismu sendiri, supaya kamu cenderung dan merasa tentram kepadanya, dan dijadikan-Nya di antaramu rasa kasih dan sayang. Sesungguhnya pada yang demikian itu benar-benar terdapat tanda-tanda bagi kaum yang berfikir. ${ }^{12}$

Menurut Islam, perkawinan dilakukan untuk memenuhi kebutuhan manusia dengan tanpa mengabaikan hak dan kewajiban suami dan istri dalam posisinya sebagai makhluk yang sama, baik di mata masyarakat ataupun di mata Allah SWT. Sebagai tolok ukur kehidupan anak hasil poligami adalah dengan membandingkan dengan keluarga lain yang ada di sekitarnya secara umum. Apabila kehidupan anak-anak keluarga poligami ini kebutuhan hidupnya serba kesulitan dan kurang terurus hidupnya, lebih memprihatinkan bila dibanding anak-anak dari keluarga lain di sekelilingnya, menunjukkan poligami ini kurang berhasil, tetapi bila kehidupan anak-anak keluarga poligami baik dari isteri tua maupun isteri muda, biasa-biasa saja sebagaimana layaknya anak-anak keluarga lain di sekelilingnya, bisa dikatakan suami yang melakukan poligami ini sudah cukup berhasil dan merupakan suami yang cukup bertanggung jawab kepada anak-anaknya sesuai dengan kemampuannya.

\section{Faktor Pendidikan Anak-Anak dalam Keluarga Poligami}

Pendidikan merupakan masalah pokok dalam kehidupan keluarga baik pendidikan formal maupun non formal, sebab pendidikan inilah yang

11 Departemen Agama RI, Al-Qur'an dan Terjemahnya..., h. 389.

12 Ibid, h. 406. 
merupakan salah satu faktor penentu masa depan dan kehidupan anak-anak mereka. Secara umum anak-anak yang mendapatkan pendidikan lebih baik masa depannya akan lebih cemerlang dan lebih berhasil dibandingkan dengan yang pendidikannya kurang mendapatkan perhatian dari orang tuanya.

Keluarga poligami yang rukun antara ayah dengan ibu saling rukun dan penuh kasih sayang, antara ibu muda dan ibu tua yang saling mengasihi dan menghormati dan si ayah (suami) mengasihi semua isterinya tanpa pilih kasih, begitu pula si ayah mengasihi anak-anaknya tanpa membeda-bedakan diantara mereka dan si ibu pun dengan ikhlas menyayangi anak-anaknya, baik anak kandungnya sendiri maupun anak tirinya tanpa terlalu membedakan dan menyebarkan benih-benih kasih sayang dan menjauhkan atau menghilangkan benih-benih pertengkaran, maka peneliti yakin anak-anak mereka akan mengikuti jejak dari ayah dan ibu mereka yang baik itu.

\section{Faktor Hubungan Antar Anak dari Keluarga Poligami}

Hubungan antara anak yang satu dengan anak yang lainnya dalam satu keluarga poligami sebenarnya merupakan masalah bagi keluarga itu sendiri, jangankan dalam keluarga poligami, dalam keluarga monogami saja hubungan antar anak sering juga terjadi ketidak cocokan dalam keluarga poligami, hubungan antar anak cukup rawan, hal ini disebabkan antara lain:

a. Adanya ketidak cocokan atau perbedaan pendapat anak dari istri tua dan istri muda. Ketidak cocokan atau perbedaan pendapat yang sangat menyolok diantara anak dari isteri tua dan anak dari isteri muda, mereka sering bersaing, saling membela ibunya masing-masing dan saudarasaudaranya sekandung, adanya kecemburuan dan kecurigaan terhadap kelompok lain dan perasaan kekhawatiran terhadap kelompok lain yang kebanyakan menyangkut masalah harta atau hak-hak yang berhubungan dengan hak milik.

b. Adanya ketidak rukunan antara saudara tiri. Akibat adanya persaingan dan ketidak cocokan antara saudara tiri, antara anak yang lahir dari ibu yang berbeda maka keluarga poligami ini terancam oleh ketidak rukunan sehingga sering terjadi cekcok, pertengkaran antara mereka dan yang lebih memperburuk keadaan apabila ibu-ibu mereka ikut mendukung masing-masing anaknya. Maka dalam keluarga tersebut akan terjadi perpecahan antara anak dari isteri pertama dengan anak dari isteri kedua, dan seterusnya.

\section{Faktor Hubungan Antara Anak Dengan Orang Tua}

Hambatan ini sama halnya hubungan antar anak-anak mereka, antar saudara kandung maupun antar saudara tiri. Kebanyakan ketidak cocokan atau ketidak rukunan di antara mereka diawali dari orang tuanya yang tidak rukun, terutama antara isteri tua dengan isteri muda dan sikap dari suami yang tidak adil dan kurang arif. Sehubungan dengan empat hambatan dari uraian di atas, dapat ditambahkan faktor penyebab yang lain yaitu: 
a. Faktor poligami yang tidak sehat

Poligami yang tidak sehat disebabkan karena antara lain:

1) Kebutuhan biologis suami.

2) Tidak memperoleh restu orang tua.

3) Belum cukup umur.

4) Tidak mendapat ijin dari isteri untuk dapat menikah lagi.

Sehingga yang dapat dilakukan adalah poligami di bawah tangan (nikah siri), hal ini akan membawa akibat yang kurang baik terhadap isteri dan anakanaknya. Karena isteri yang dinikah di bawah tangan tidak memiliki kekuatan hukum begitu juga anak-anak yang dilahirkan digolongkan anak luar nikah yang hanya mempunyai hubungan perdata terhadap ibunya dan keluarga ibunya, seperti diatur dalam pasal 43 ayat (1) UU no 1 Tahun 1974.

\section{Faktor Tidak Diajukan Gugat Nafkah Anak}

Dasar gugatan kiranya dapat diupayakan agar suami memenuhi kebutuhan hidup keluarganya. Akan tetapi kenyataannya isteri yang dipoligami tidak pernah mengajukan gugatan nafkah, baik untuk dirinya maupun untuk anak-anaknya, padahal ini merupakan haknya sebagai isteri yang dapat melindungi anak-anaknya. Tidak diajukan gugatan nafkah karena mereka umumnya tidak mengerti tentang prosedur berperkara di pengadilan, kesadaran mereka yang masih kurang dalam mempertahankan haknya dan adanya rasa enggan untuk membawa masalah itu ke pengadilan, karena poligaminya di bawah tangan. Apabila isteri tidak mampu menahan beban hidup yang dikarenakan suami melalaikan kewajiban, biasanya isteri akan mengajukan perceraian, namun perceraian yang dimaksud tentunya tidak seperti perceraian yang ada dalam perkawinan yang diatur dalam UU No 1 Tahun 1974, karena perkawinan di bawah tangan tidak dicatat dan tidak melalui prosedur perundang-undangan maka model percerainnyapun dengan bubar begitu saja, hal ini sangat berakibat buruk terhadap perlindungan dan pemeliharaan anak.

Upaya Penanggulangan Hambatan Pelaksanaan Perlindungan Hukum terhadap Anak dalam Keluarga Poligami di Kota Metro Ditinjau dari Hukum Islam dan Positif sebagai berikut:

a. Menegakkan Kepemimpinan Suami dalam Keluarga

Suami bukanlah seorang diktator yang harus bertindak diktator terhadap anak dan isterinya, tetapi suami bagaimanapun juga keadaannya sebagai pekerja dan status sosialnya merupakan pemimpin keluarga. Walaupun pendidikan isteri-isterinya lebih tinggi, gaji isteriisterinya lebih besar tetapi dalam kehidupan keluarga suamilah sebagai pemimpin keluarga. Allah SWT berfirman dalam Q.S. An-Nisa ayat 34. 
"Laki-laki adalah pemimpin bagi wanita dengan kelebihan yang diberikan oleh Allah atas sebagian mereka ( laki-laki) atau sebagian yang lainnya ( wanita )."13

Kedudukan ini harus disadari isteri-isteri sehingga dia taat kepada suaminya, selama suami tidak mengajak pada perbuatan kemungkaran dan kebatilan serta kekufuran. Suami sebagai pemimpin rumah tangga tidak boleh ditaktor walaupun berkuasa, tetapi harus menggunakan kekuasaannya dengan sebaik-baiknya sebab dia harus mempertanggung jawabkannya dihadapan Allah di akhirat nanti.

b. Obyektivitas dan Netralitas Suami

Dalam melaksanakan kepemimpinannya sebagai kepala keluarga kususnya dalam kehidupan poligami, suami harus bertindak netral dan obyektif. Suami bersikap netral artinya tidak memihak salah satu isterinya atau sekelompok anaknya, sebab apabila suami memihak pada salah satu pihak akan terjadi kelompok yang merasa dibela dan ada kelompok yang merasa dianak tirikan atau dirugikan sehingga kurang simpati kepada suami/ayah tersebut.

c. Keadilan Suami

Upaya untuk mengatasi permasalahan keluarga selanjutnya tergantung pada keadilan suami terhadap isteri-isterinya, baik permasalahan yang kecil maupun yang besar, mulai dari pembagian hari sampai kebutuhan keluarga secara menyeluruh. Tindakan adil dari suami ini merupakan kelanjutan dari sikap obyektif dan netralitas suami dilandasi sikap berfikir rasional tidak emosional. Bila suami bertindak tidak adil terhadap isteri-isterinya atau anak-anaknya berarti dia telah memihak salah satu pihak, menguntungkan salah satu pihak dengan merugikan pihak lainnya, hal ini dapat berakibat fatal dalam kehidupan poligami.

Suami sudah seharusnya selalu berusaha menjaga keseimbangan anatara mereka, menjaga prinsip keadilan terhadap isteri-isteri dan anakanaknya. Dalam kaidah ilmu hukum menyebutkan 'Summum Ius Summa Iniuria' (keadilan yang tertinggi adalah ketidak adilan yang tertinggi). Prinsip ini tampaknya salah tetapi sesungguhnya mengandung nilai kebenaran, karena keadilan manusia secara maksimal terutama yang menyangkut kuantitas akhirnya malah merupakan suatu ketidak adilan hukum, sebab tujuan hukum tidak semata-mata ketidak adilan tetapi juga kegunaan bagi manusia. Dalam kehidupan keluarga kususnya keluarga poligami, suami sejauh mungkin berusaha bertindak adil, dalam pengertian adil komutatif maupun distributif. Dia harus tahu kapan dia bertindak adil secara komutatif dan kapan secara distributif.

d. Suami Bertindak Bijaksana

${ }^{13}$ Kementerian Agama RI, Al-Qur'an dan Terjemahnya..., h. 230. 
Antara keadilan dan kebijaksanaan merupakan dua hal yang tidak dapat dipisahkan, tetapi bukan mustahil suatu kebijaksanaan dapat merusak suatu peraturan. Peraturan hukum pelaksanaannya memang tidak harus kaku, masih perlu adanya kebijaksanaan dalam pelaksanaannya, sehingga pelaksanaannya bisa luwes. Terpenting suami bertindak bijaksana, hingga mampu mengarahkan perasaan isteriisterinya menuju hal-hal yang bersifat positif, demi keutuhan keluarga mereka sendiri dan bilamana terjadi problem antara mereka (isteri-isteri) suami mampu secara cepat untuk mengatasinya.

Keadilan komutatif atau sama rata, sama rasa berdasarkan kuantitas bukan semata-mata menggunakan rasio, melainkan lebih banyak menggunakan perasaan. Melalui kebijaksanaan yang dimilikinya, suami mampu mengatur isteri-isterinya dan mengatasi problem keluarga yang menyangkut hubungan internal keluarga mereka, sehingga untuk mengatasi problem antar mereka juga banyak menggunakan senjata perasaan ini. Terpenting suami bertindak bijaksana, hingga mampu mengarahkan perasaan isteri-isterinya menuju hal-hal yang bersifat positif, demi keutuhan keluarga mereka sendiri dan bilamana terjadi problem antara mereka (isteri-isteri) suami mampu secara cepat untuk mengatasinya.

e. Kasih Sayang Suami

Kasih sayang suami terhadap isteri-isteri dan anak-anaknya merupakan tiang pokok dalam kehidupan dan ketentraman keluarga, tindakan suami tidak boleh didasarkan kebencian ataupun balas dendam walaupun dia memarahi salah satu atau semua isterinya, begitu pula sikapnya terhadap anak-anaknya. Dia tahu kapan memarahi, kapan memberi pujian, kapan meberikan hadiah, dan seterusnya, yang penting tindakan seorang suami bukan didasarkan kebencian dan balas dendam tetapi didasarkan kasih sayang dan cinta mencintai.

Apabila suami bersikap kasih sayang terhadap isteri-isterinya dan anak-anak mereka maka isteri-isterinya sebaliknya akan memberikan kasih sayang kepada suaminya, begitu pula anak-anak akan mengasihi dan menyayangi ayahnya, akan menghormati dan simpati pada ayahnya, dan apabila terjadi problem di rumah tangga akan mudah diselesaikan dengan baik.

f. Suami Dapat Menjaga Keseimbangan Hak dan Kewajiban

Dalam kehidupan keluarga kususnya keluaraga poligami, permasalahan keluarga sering terjadi karena masing-masing orang yang terlibat di dalamnya berusaha untuk mendapatkan hak yang lebih besar tanpa diikuti dengan pelaksanaan kewajiban dengan baik, mungkin suami mengharuskan isteri-isterinya melayaninya dengan baik tapi kewajibannya kurang dipikirkan, mungkin isteri tua mnuntut bagian lebih banyak, belanja lebih banyak, bagian hari giliran datangnya suami 
lebih banyak dan hak-hak lain yang lebih besar tanpa menghiraukan kewajibannnya sebagai isteri atau sebagai ibu.

Istri sudah seharusnya menghormati suami, karena dengan demikian dia (isteri) akan memberikan contoh yang baik terhadap anakanaknya. Isteri atau ibu yang penuh kasih sayang pada suaminya dan menjalankan kewajibannya sebagai isteri dengan baik tanpa banyak menuntut macam-macam hak yang melewati batas kemampuan suami, yang demikian ini disebut wanita sholehah atau isteri shalehah.

\section{Simpulan}

Pelaksanaan perlindungan hukum terhadap anak dalam keluarga poligami di Kota Metro ditinjau dari hukum Islam dan hukum positif adalah hukum positif, dari sisi hadhana (pemeliharaan anak) dalam keluarga poligami di Kota Metro berjalan pada tingkat mengasuh dan merawat, memenuhi semua kebutuhan hidup dan menjaga kehormatan dari segi gangguan, membimbing dan mendidik serta memelihara kesehatan dan kesejahteraan belum terlaksanan dengan baik dan hukum Islam, ada yang terlaksana dengan baik. Faktor-faktor yang menghambat pelaksanaan perlindungan hukum terhadap anak dalam keluarga poligami di Kota Metro adalah: faktor Kebutuhan Anak-anak Poligami, faktor Pendidikan Anak-anak dalam keluarga poligami, faktor hubungan antar anak dari keluarga poligami, faktor hubungan antara anak dengan orang tua. Upaya penanggulangan terhadap hambatan yang terjadi dalam keluarga poligami di Kota Metro adalah menegakkan kepemimpinan suami dalam keluarga, obyektivitas dan netralitas suami, keadilan suami, suami bertindak bijaksana, kasih sayang suami, suami berani mengalah demi kerukunan keluarga, dan suami dapat menjaga keseimbangan hak dan kewajiban.

\section{Referensi:}

Abdurrahman, Kompilasi Hukum Islam di Indonesia, Jakarta: Akademika Pressindo, 2010.

Abu Huraerah, Child Abuse (Kekerasan terhadap Anak), Bandung: Nuansa, 2007.

Ali Afandi, Hukum Waris, Hukum Keluarga, Hukum Pembuktian Menurut Kitab UndangUndang Hukum Perdata (BW), Jakarta: PT. Bina Aksara, 1984.

Al-Sijistany, Abu Dawud Sulaiman al-Asy'ast Sunan Abu Dawud, Kitab: Al Adab bab: Fi Taghyiri al Asma', Riy adh: Maktabah al Ma'arif Li al-Nasyr wa at-Tawzi.

Departemen Agama RI, Al-Qur'an dan Terjemahnya, Jakarta: Pustaka Al Fatih, 2009.

Lembaran Negara RI, UU No. 23 Tahun 2002 tentang Perlindungan Anak dan UU No. 35 Tahun 2004 tentang Perubahan atas UU Mo. 23 Tahun 2002 tentang Perlindungan Anak pasal 1 ayat 1.

Selamat Kasmuri, Pedoman Mengayuh Bahtera Rumah Tangga, Jakarta: Kalam Mulia, 1998.

Seri Perundangan, Kompilasi Hukum Islam, Yogyakarta: Pustaka Widyatama, 2005. 